\title{
Efficacy of aggregation nano gel pheromone traps on the catchability of Rhynchophorus ferrugineus (Olivier) in Egypt
}

\author{
A. S. AbdEl-Wahab * (D), A. Y. Abd El-Fattah ${ }^{a}$ (D), W. K. M. El-Shafei ${ }^{b}$ (D) and A. A. El-Helaly

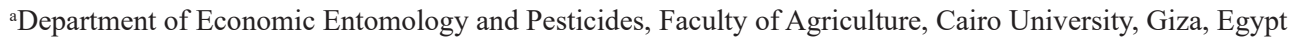 \\ bDepartment of Date Palm Pests and Diseases, Central Laboratory for Date Palm, Agricultural Research Center ARC, \\ Giza, Egypt \\ *e-mail: abeer5698987@yahoo.com
}

Received: December 6, 2019 - Accepted: March 23, 2020 - Distributed: March 31, 2021

(With 7 figures)

\begin{abstract}
Field experiments were carried out in the reclaimed land east of Cairo-Alexandria Desert Road, Village of Wardan, Giza Governorate, Egypt, to evaluate the impact of using nano-gels pheromone for the first time on the attraction of the RPW adults by pheromone traps compared to the control which is normal pheromone during two successive seasons in 2018 and 2019. Also, this study aimed to compare the efficacy of two types of trap, traditional trap (type 1) and dry funnel trap (type 2) in capturing of RPW adults. Results revealed that the nano gel pheromone traps attracted significantly more adults with an average of (4.26 and 3.56) adults/trap and total of (55.33 and 46.33) adults/trap compared to control with an average (2.69 and 2.46) and total of (35.00 and 32.00) adults/trap for the two seasons 2018 and 2019 respectively. Results indicated that the use of nano gel pheromone for the first time in field improved the trap catchability to RPW adults by 22.51 and $18.30 \%$ of total number of RPW adults captured throw out the two successive seasons respectively. In addition, there was no significant difference between the total numbers of RPW adults collected by the two tested type of traps over the two successive seasons. Furthermore, the sex ratio between males and females of total collected RPW adults found to be1: 1.43 and 1: 1.94 at 2018 and 2019 respectively.
\end{abstract}

Keywords: nano-gels pheromone, Rhynchophorus ferrugineus, RPW trap, aggregation pheromone, traditional trap.

\section{Eficácia das armadilhas de feromônio de nano gel de agregação na capturabilidade de Rhynchophorus ferrugineus (Olivier) no Egito}

\begin{abstract}
Resumo
Experimentos de campo foram realizados na terra recuperada a leste da estrada do deserto de Cairo-Alexandria, vila de Wardan, província de Giza, Egito, para avaliar o impacto do uso de feromônio de nano géis pela primeira vez na atração de adultos RPW por armadilhas de feromônio comparado ao controle que é o feromônio normal durante duas temporadas sucessivas em 2018 e 2019. Além disso, este estudo teve como objetivo comparar a eficácia de dois tipos de armadilha, armadilha tradicional (tipo 1) e armadilha de funil seco (tipo 2) na captura de RPW adultos. Os resultados revelaram que as armadilhas de nano gel de feromônio atraíram significativamente mais adultos, com uma média de $(4,26$ e 3,56) adultos/ armadilha e total de $(55,33$ e 46,33) adultos/armadilha em comparação ao controle com uma média $(2,69$ e 2,46$)$ e total de (35.00 e 32.00) adultos/armadilha para as duas temporadas 2018 e 2019, respectivamente. Os resultados indicaram que o uso de feromônio nano gel pela primeira vez em campo melhorou a capturabilidade de armadilhas para adultos com RPW em 22,51 e 18,30\% do número total de adultos com RPW capturados durante as duas estações sucessivas, respectivamente. Além disso, não houve diferença significativa entre o número total de adultos RPW coletados pelos dois tipos de armadilhas testados ao longo das duas estações sucessivas. Além disso, a proporção sexual entre homens e mulheres do total de adultos coletados de RPW foi de 1: 1,43 e 1: 1,94 em 2018 e 2019, respectivamente.
\end{abstract}

Palavras-chave: nano géis feromônio, Rhynchophorus ferrugineus, armadilha RPW, feromônio de agregação, armadilha tradicional.

\section{Introduction}

The different cultivars of date palm Phoenix dactylifera L and ornamental palms Phoenix canariensis attacked by different species of insects especially red palm weevil
Rhynchophorus ferrugineus (RPW) (Olivier) (Coleoptera: Curculionidae) which has become a global palm destroyer pest (Habib et al., 2017; Milosavljevic et al., 2019). 
According to Salem et al. (2018) the red palm weevil have spread around the world in more than 50 countries because of transportation of infested palm trees to other countries which are free of RPW infestation. In addition, sever fliers which it can fly more than $900 \mathrm{~m}$ in $24 \mathrm{hrs}$. and during 3-5 days it can fly over $7 \mathrm{~km}$ (Abbas et al., 2006). The beginning of the invasion of red palm weevil in the Gulf region in mid-1980s in UAE 1985 and Kingdom of Saudi Arabia in 1987 then, in 1992 the RPW was recorded for the first time in Egypt and after that it spread to many countries (Cox, 1993). The RPW infest more than nearly 40 palm species around the world (Al-Saroj et al., 2017; Al-Dosary et al., 2016). The internal tissues were damages by the larval stages which is the serious stage as results of penetrates to the stem of palm which makes difficult to control this pest (Vacas et al., 2013). It is difficult to detect infestation in its early stages due to the absence of any symptoms of the injury as results of hidden larvae feeding (Hoddle et al., 2013; Milosavljević et al., 2019).

El-Sabea et al. (2009) reported that the annual loss of infested palm by RPW removal ranged from 1 to $5 \%$ of palm in the Middle East cost from $\$ 5.18$ to $\$ 25.92$ million, respectively.

This pest was controlled using several methods include chemical control which is mainly to control the RPW although contamination of Environment and other strategies, biological control and the pheromone traps which conceder one of the important ways to control RPW and Environment safety (El-Banna et al., 2017). A lot of efforts have been made since three decades up to date to solve this problem; one of newest solution raised is using nano pesticides (Abd El-Fattah et al., 2019). Using the aggregation pheromone traps is a promise technology to capture and kill the RPW (Faleiro et al., 2016). Currently managed of RPW under the strategy of Integrated Pest Management (IPM) by using aggregation pheromone which used in monitoring and mass trapping (Abraham et al., 1998). According to Hallett et al. (1993) the male of RPW produced the aggregation pheromone which consisted of two components (4-methyl-5- nonanol (ferrugineol) with market name Ferrolure and 4-methyl-5-nonanol+4methyl-5-nonanone in proportion 90:10 (marketed under the name of Ferrolure+ (Mahmud et al., 2015). The trap components and design is important to achieved high capture where is the trap that contents water, lure, bait and Kairomone achieve high capture in addition the traps servicing (AL-Saroj et al., 2017). Al-Saoud and Ajlan (2013) revealed that trap color played a very important role to high capture where it the drake traps captured high number of weevil compared to other colors. Oehlschlager (1994) recommended to used 1 trap/ha in mass trapping which increasing according to activity of RPW in the field to 4-10traps/ha (Faleiro et al., 2011). Recently the pheromone trap has been developed with dry traps (Electrap $\left.{ }^{\mathrm{TM}}\right)$ with service less and comparative with traditional trap (ALSaroj et al., 2017). The aim of this study to evaluate the efficiency of using nano gels pheromone for the first time in the attraction of RPW adults by Aggregation pheromone trap and compare between two trap types, traditional trap and dry funnel trap.

\section{Material and Methods}

\subsection{Location of experiment}

The experiment was carried out at a palm farm in the reclaimed land east of Cairo-Alexandria Desert Road, Village of Wardan Coordinate in Giza Governorate for two successive seasons (Early March to the end of May each year of 2018 and 2019) to study the efficiency of aggregation pheromone that loaded in Nano gel and compare to normal pheromone under field conditions and also, compare between two trap types depending on the average and total numbers of attracted adults.

\subsection{Preparation of nano gel pheromone}

\subsubsection{Synthesis of nano carrier (chitosan nanoparticles)}

One capsule of RPW aggregation Pheromone was divided into six parts and each part was loaded onto the nano-gelas well as the control. $R$. ferrugineus aggregation pheromone containing $700 \mathrm{mg}$ of the active ingredient (4-Methyl-5-Nonanol (9 parts) + 4-Methyl-5-Nonanol (one part)) (Pheromone lure was manufactured by Chim Tica international S.A. Company, Costa Rica. Trade Name PO28 Ferroluree+, 700mg lure, consists of a mixture of 4-methyl 5-nonanol and 4-methyl 5-nonanone (9:1 part purity of both components $>95 \%$ release rate $3-10 \mathrm{mg} /$ day). Chitosan nano particles were prepared according to the ionotropic gelation process according to Hasanin et al. (2018). Blank nano particles were obtained upon the addition of a tri-polyphosphate (TPP) aqueous solution to a chitosan solution.

\subsubsection{Loading of pheromone onto chitosan nanoparticles:}

The chitosan nanoparticles were dispersed in distilled $\mathrm{H} 2 \mathrm{O}$ then, the pheromone was dispersed into chitosan solution at ration $10 \%$ with stirring for $1 \mathrm{~h}$ to get well dispersion and loading.

\subsubsection{Preparation of gel}

Polyethylene oxide powder was added in concentration $4 \%$ to make the previous composite in gel form for further investigation Figure 1.

\subsection{Traps design}

The experiment was carried out using two black types of pheromone traps siting in the ground shadow and surrounded by sand until near the holes in the sides of the trap to facilitate the entry of RPW adults to the trap through the holes for the traditional trap and through the funnel for the dry trap.

The two traps were prepared by 10-liter plastic bucket and both the body of the bucket and its cover were painted with adhesive paint. Then, the coarse sand was sprayed onto the whole bucket from outside to stick the coarse sand grains to facilitate walking of RPW adults to reach 

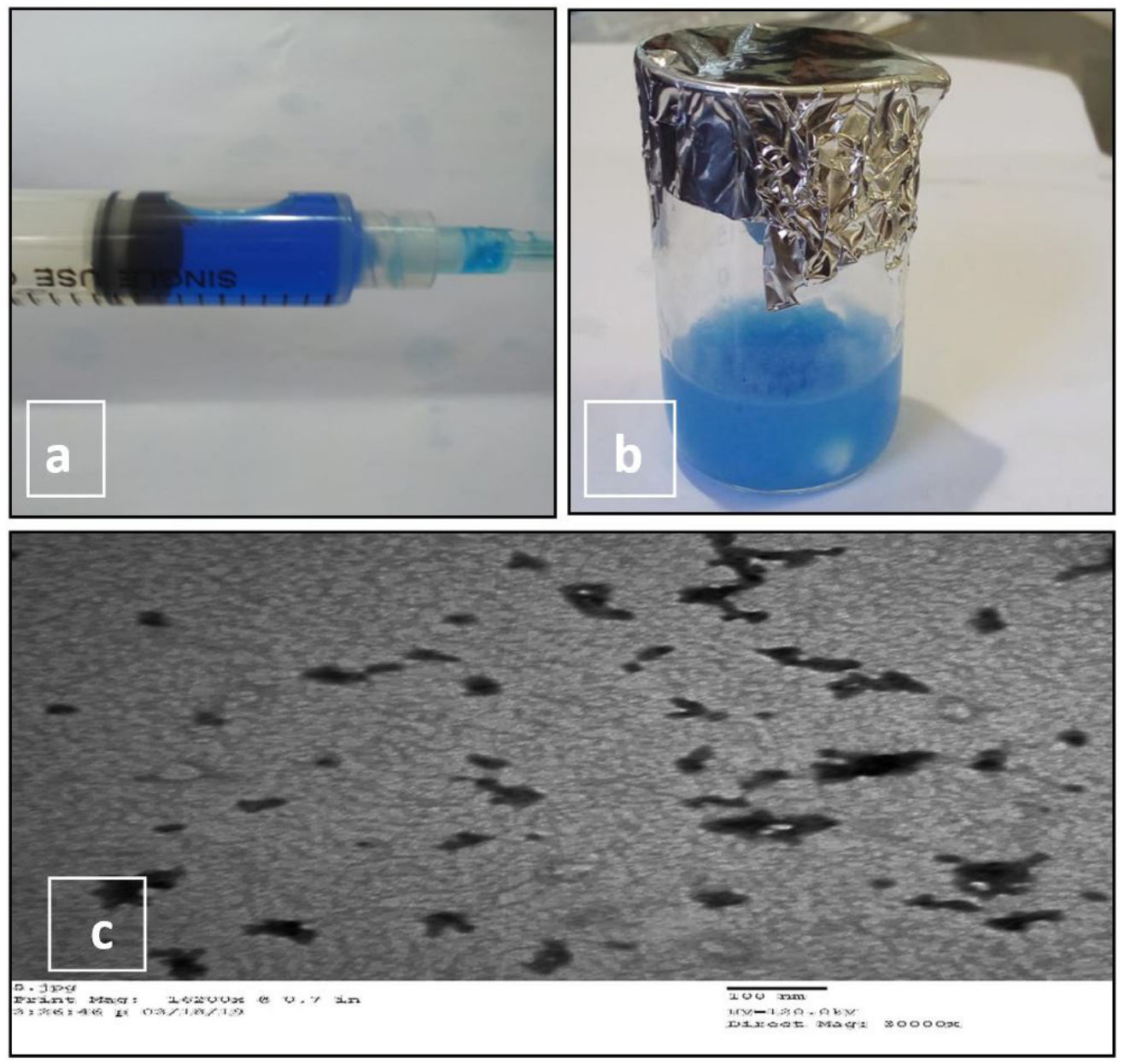

Figure 1. (a) RPW aggregation pheromone (b) Nano gels Pheromone (c) TEM image of nano gels pheromone.

the holes in trap type 1 or the funnel in the case of dry trap type 2 (Esco trap) designed by Ibn El-waleed from Esco Company. Then leave a day to dry and then paint in black because, the drake traps captured high number of weevil compared to other colors Al-Saoud and Ajlan (2013).

Trap types:

\section{a) Type1(traditional)}

This trap containing aggregation pheromone, kairomone, and $500 \mathrm{~g}$ of sugar cane (renewed every month) and5 liters of water(renewed every 15 days) illustrated in Figures 2 and 3 . This trap has 4 holes $3 \times 7 \mathrm{~cm}$ around the trap body and 3 other holes on its cover (Abuagla and Al-Deeb, 2012; Al Saoud and Ajlan, 2013; Al Saoud et al., 2016; Gilal et al., 2017).

b) Type 2(dry funnel)

This trap containing only the aggregation pheromone and kairomone (without food bait or water) and it has one hole in the cover $(3.5 \times 18 \mathrm{~cm})$ with a funnel installed on the cover of the trap. This funnel equipped with a set of thorns that allow the insects to enter and does not allow it to exit where it is considered a simulator of a trap Electrap ${ }^{\mathrm{TM}}$ illustrated in Figures 2 and 3.

\subsection{Field experiment}

Twelve traps were used 6 form traditional traps ( 3 traps contain nano gel pheromone and 3 of the control) and 6 traps representing the trap types ( 3 traps from type 1 and 3 traps from type 2 ). These traps were placed in shadow and at equal distances of 50 meters between the trap and the other (Al-Saoud et al., 2010, 2016; Hashim et al., 2013).

\subsection{Statistical analysis}

Data were analyzed using Proc., ANOVA in SAS (SAS Institute, 2006).

\section{Results and Discussion}

\subsection{Impact of nano gel pheromone on the attraction of the RPW adults by pheromone trap during two} successive seasons in 2018 and 2019

Data presented in Table 1 and illustrated in Figures 4 and 5 showed impact of using nano gel pheromone for the first time on the attraction of the RPW adults by 


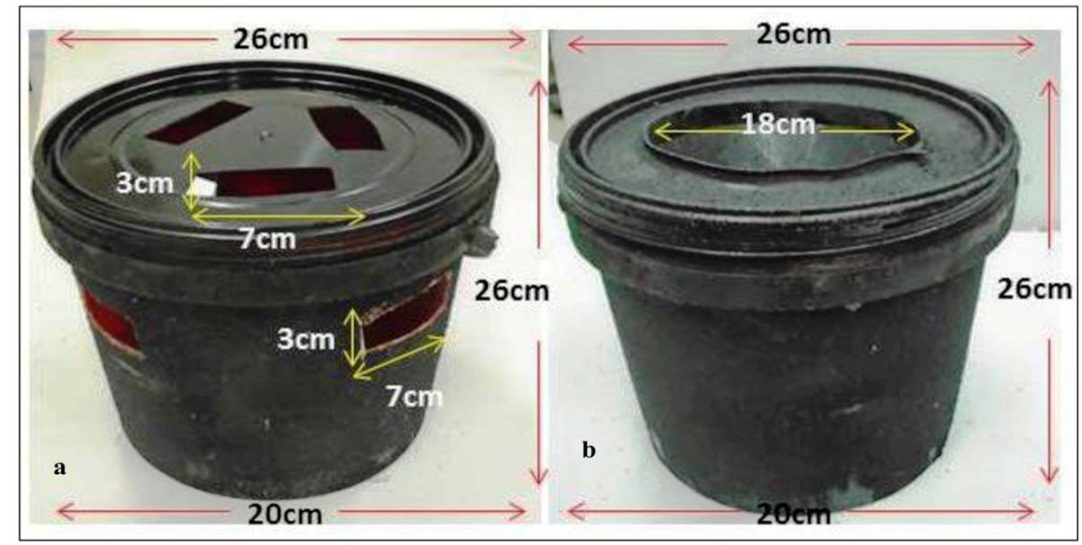

Figure 2. Specification and measurements of the two trap types used in the experiments: (a) Type 1 (traditional trap) (b) Type 2 (dry funnel trap).
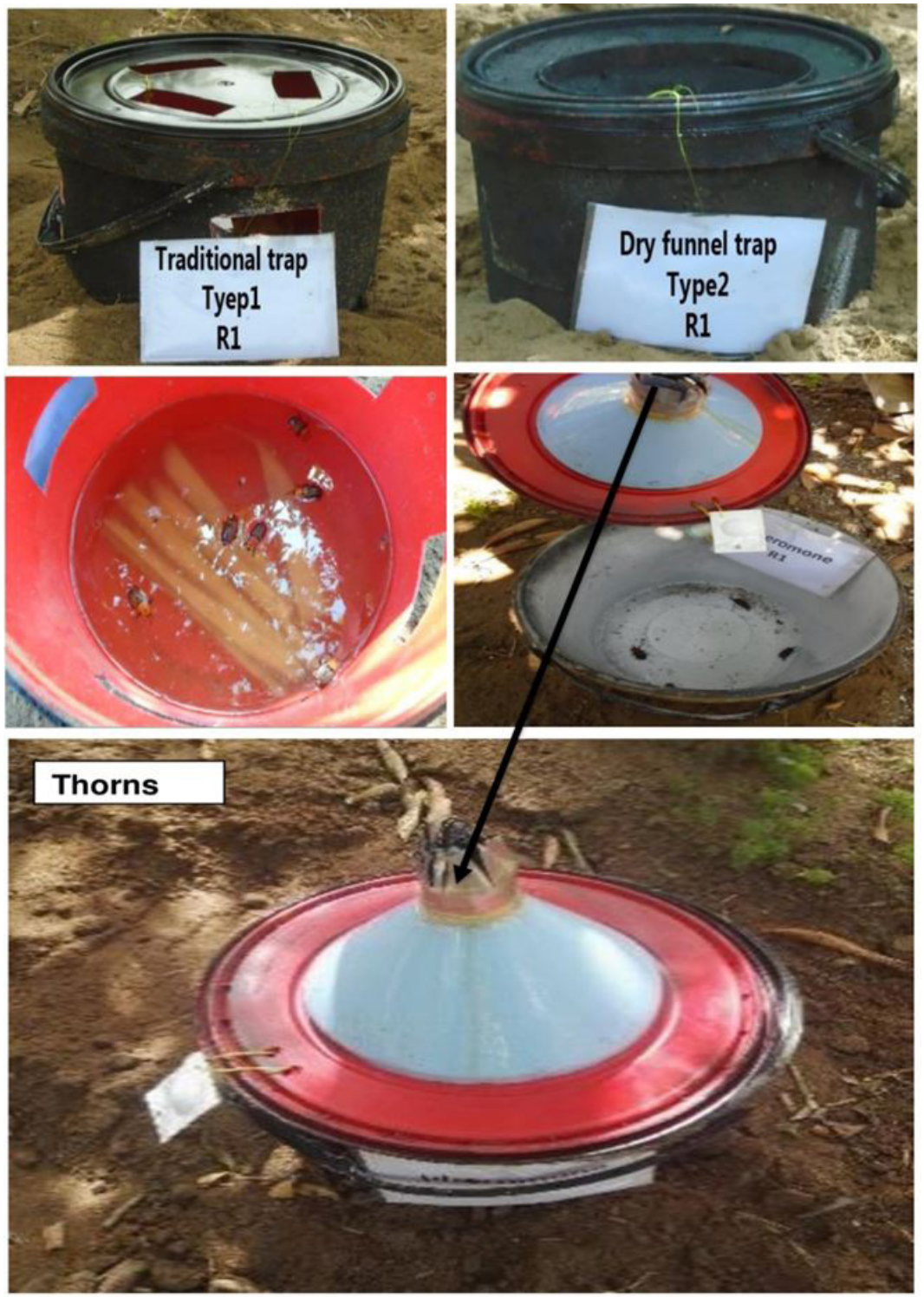

Figure 3. The two types of traps used in the experiment in the field. 
Table 1. Number of RPW adults captured by Nano Gel Pheromone trap during 2018 and 2019 compered to control.

\begin{tabular}{|c|c|c|c|c|c|c|c|c|c|c|c|c|}
\hline \multirow{4}{*}{$\begin{array}{l}\text { Weeks } \\
\text { week1 }\end{array}$} & \multicolumn{12}{|c|}{ Seasons } \\
\hline & \multicolumn{6}{|c|}{2018} & \multicolumn{6}{|c|}{2019} \\
\hline & \multicolumn{3}{|c|}{$\begin{array}{c}\text { Control pheromone } \\
(\text { Mean } \pm \text { SD })\end{array}$} & \multicolumn{3}{|c|}{$\begin{array}{c}\text { Nano Gel Pheromone } \\
(\text { Mean } \pm \text { SD) }\end{array}$} & \multicolumn{3}{|c|}{$\begin{array}{c}\text { Control pheromone } \\
(\text { Mean } \pm \text { SD })\end{array}$} & \multicolumn{3}{|c|}{$\begin{array}{c}\text { Nano Gel Pheromone } \\
(\text { Mean } \pm \text { SD) }\end{array}$} \\
\hline & 4.00 & \pm & 1.73 & 3.33 & \pm & 2.31 & 3.67 & \pm & 2.52 & 3.67 & \pm & 1.00 \\
\hline week2 & 6.33 & \pm & 2.31 & 5.00 & \pm & 3.61 & 5.67 & \pm & 0.58 & 4.67 & \pm & 1.53 \\
\hline week3 & 2.00 & \pm & 1.00 & 5.33 & \pm & 4.04 & 2.67 & \pm & 1.15 & 4.67 & \pm & 1.00 \\
\hline week4 & 5.00 & \pm & 1.73 & 6.33 & \pm & 1.15 & 5.33 & \pm & 2.52 & 6.67 & \pm & 1.00 \\
\hline week 5 & 2.00 & \pm & 2.00 & 5.00 & \pm & 1.00 & 3.00 & \pm & 2.00 & 3.33 & \pm & 1.15 \\
\hline week6 & 2.33 & \pm & 2.52 & 5.33 & \pm & 2.52 & 1.33 & \pm & 0.58 & 5.00 & \pm & 1.53 \\
\hline week7 & 2.00 & \pm & 1.00 & 5.33 & \pm & 1.53 & 1.00 & \pm & 1.00 & 3.67 & \pm & 0.58 \\
\hline week8 & 2.67 & \pm & 1.53 & 3.67 & \pm & 0.58 & 3.33 & \pm & 0.58 & 4.00 & \pm & 0.58 \\
\hline week9 & 1.67 & \pm & 1.53 & 4.00 & \pm & 2.65 & 0.67 & \pm & 0.58 & 3.33 & \pm & 0.58 \\
\hline week10 & 2.00 & \pm & 1.00 & 5.00 & \pm & 2.65 & 2.00 & \pm & 2.65 & 2.67 & \pm & 1.00 \\
\hline week11 & 2.33 & \pm & 1.53 & 4.00 & \pm & 1.73 & 1.00 & \pm & 1.00 & 2.33 & \pm & 0.58 \\
\hline week12 & 2.00 & \pm & 1.00 & 2.33 & \pm & 1.53 & 2.00 & \pm & 1.00 & 2.00 & \pm & 1.73 \\
\hline week13 & 0.67 & \pm & 0.58 & 0.67 & \pm & 1.15 & 0.33 & \pm & 0.58 & 0.33 & \pm & 0.58 \\
\hline Total & \multicolumn{3}{|c|}{$\mathbf{3 5 . 0 0}$} & \multicolumn{3}{|c|}{55.33} & \multicolumn{3}{|c|}{32.00} & \multicolumn{3}{|c|}{46.33} \\
\hline Mean & \multicolumn{3}{|c|}{$2.692^{b}$} & \multicolumn{3}{|c|}{$4.256^{\mathrm{a}}$} & \multicolumn{3}{|c|}{$2.461^{\mathrm{b}}$} & \multicolumn{3}{|c|}{$3.564^{a}$} \\
\hline L.S.D. & \multicolumn{6}{|c|}{0.989} & \multicolumn{6}{|c|}{1.0415} \\
\hline
\end{tabular}

${ }^{a}=$ significant difference highly exist; ${ }^{b}=$ significant difference exist; L. S. D. least significant difference; S.D. $=$ significant difference.

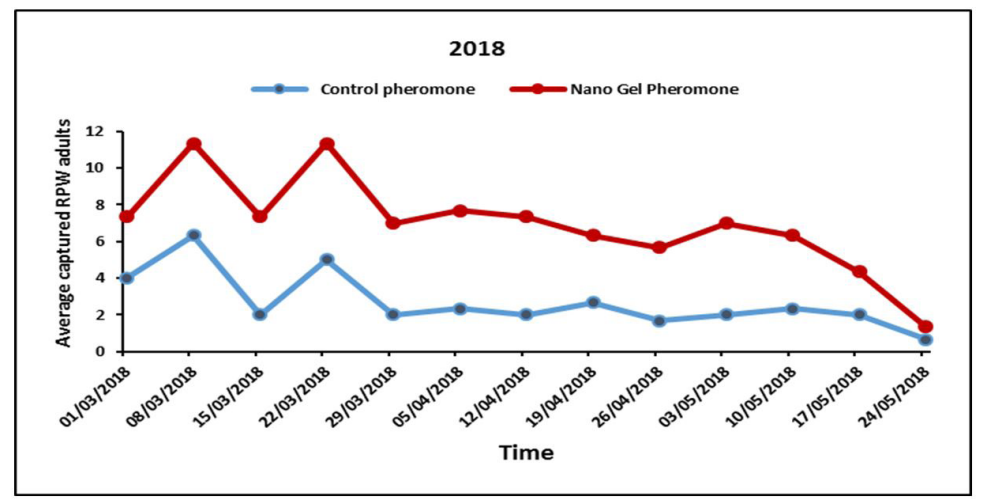

Figure 4. Number of RPW adults captured by Nano Gel Pheromone trap during 2018 compared to control.

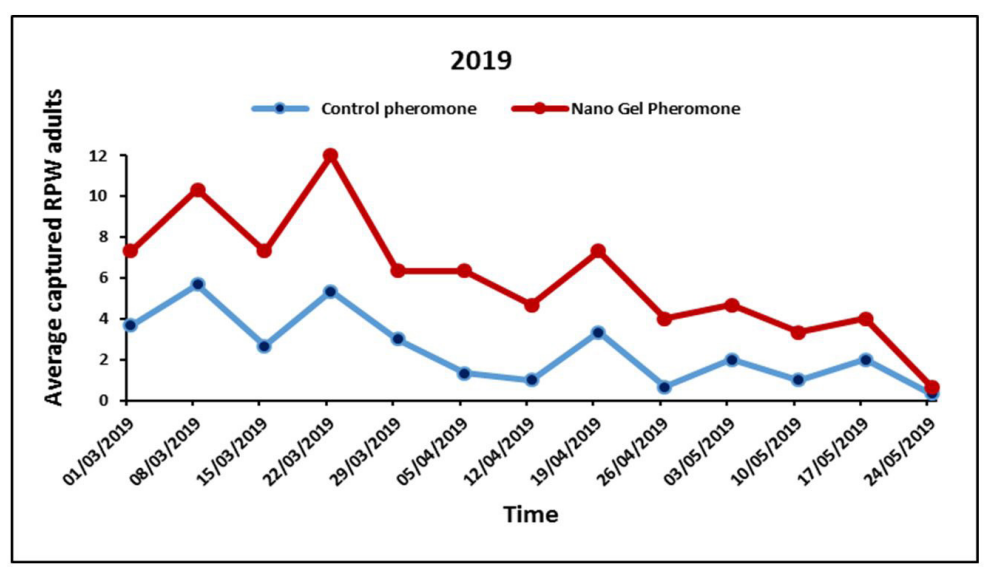

Figure 5. Number of RPW adults captured by Nano Gel Pheromone trap during 2019 compared to control. 
pheromone trap compared to the control which is normal pheromone during two successive seasons in 2018 and 2019. Data indicated that the trap contained nano gel pheromone attracted significantly more adults with an average of (4.26 and 3.56) adults/trap and total of (55.33 and 46.33) adults/trap compared to control with an average of (2.69 and 2.46) and total of (35.00 and 3.200) adults/trap for the two seasons 2018 and 2019 respectively. These results revealed that, using nano gel pheromone for the first time in this field improved the trap catchability to RPW adults by 22.51 and $18.30 \%$ of total number of RPW captured adults for the two seasons 2018 and 2019 respectively. Our results are in agreement with those of Bhagat et al. (2013) who reported that in particular the involvement of the nano-gelled pheromone when they achieved d effective management of Bactrocera dorsalis, , a widespread harmful pest for a number of fruits. El-bendary et al. (2016) studied in the Egypt the toxicity of nano-zinc oxide and nanoaluminum oxide against rice weevil, Sitophilus oryzae under laboratory conditions, and the results showed that nano-aluminum oxide was more effective than nano-zinc oxide and malathion. El-Helaly et al. (2016) evaluated the effect of silica-nano particles in comparison with silica and diazinon in control Spodoptera littoralis (Bosid.) under laboratory and semi- field condition, the results showed that nano- silica caused more toxic than the other treatments.

3.2. Comparison between two types of trap and its influence on captured adults of RPW during 2018 and 2019

Data presented in Table 2 and illustrated in Figure 6 showed the comparison between two types of aggregation pheromone trap type 1 which is the traditional

Table 2. Comparison between two types of trap and its influence on captured adults of RPW during 2018 and 2019.

\begin{tabular}{|c|c|c|c|c|c|c|c|c|c|c|c|c|}
\hline \multirow{4}{*}{$\begin{array}{l}\text { Weeks } \\
\text { week1 }\end{array}$} & \multicolumn{12}{|c|}{ Seasons } \\
\hline & \multicolumn{6}{|c|}{2018} & \multicolumn{6}{|c|}{2019} \\
\hline & \multicolumn{3}{|c|}{$\begin{array}{l}\text { Type } 1 \text { traditional } \\
\text { trap }(\text { Mean } \pm \text { SD) }\end{array}$} & \multicolumn{3}{|c|}{$\begin{array}{l}\text { Type } 2 \text { dry funnel } \\
\text { trap (Mean } \pm \text { SD) }\end{array}$} & \multicolumn{3}{|c|}{$\begin{array}{l}\text { Type } 1 \text { traditional } \\
\text { trap }(\text { Mean } \pm \text { SD) }\end{array}$} & \multicolumn{3}{|c|}{$\begin{array}{l}\text { Type } 2 \text { dry funnel } \\
\text { trap (Mean } \pm \text { SD) }\end{array}$} \\
\hline & 7.33 & \pm & 3.51 & 10.67 & \pm & 5.51 & 7.33 & \pm & 1.15 & 8.33 & \pm & 2.52 \\
\hline week2 & 11.33 & \pm & 5.51 & 11.67 & \pm & 3.06 & 10.33 & \pm & 3.06 & 8.33 & \pm & 2.08 \\
\hline week3 & 7.33 & \pm & 3.51 & 3.67 & \pm & 2.08 & 7.33 & \pm & 2.08 & 4.33 & \pm & 0.58 \\
\hline week4 & 11.33 & \pm & 2.52 & 12.33 & \pm & 2.08 & 12.00 & \pm & 4.58 & 12.33 & \pm & 4.04 \\
\hline week5 & 7.00 & \pm & 2.65 & 5.33 & \pm & 0.58 & 6.33 & \pm & 0.58 & 4.33 & \pm & 1.53 \\
\hline week6 & 7.67 & \pm & 4.04 & 6.33 & \pm & 1.15 & 6.33 & \pm & 4.04 & 4.00 & \pm & 1.00 \\
\hline week7 & 7.33 & \pm & 2.31 & 13.33 & \pm & 2.08 & 4.67 & \pm & 2.89 & 14.00 & \pm & 4.00 \\
\hline week8 & 6.33 & \pm & 2.08 & 4.33 & \pm & 3.21 & 7.33 & \pm & 2.08 & 4.67 & \pm & 2.52 \\
\hline week9 & 5.67 & \pm & 1.53 & 6.33 & \pm & 4.51 & 4.00 & \pm & 2.00 & 5.33 & \pm & 3.51 \\
\hline week10 & 7.00 & \pm & 3.46 & 6.33 & \pm & 1.15 & 4.67 & \pm & 2.31 & 4.33 & \pm & 1.15 \\
\hline week11 & 6.33 & \pm & 3.06 & 2.67 & \pm & 1.15 & 3.33 & \pm & 2.08 & 1.00 & \pm & 1.00 \\
\hline week12 & 4.33 & \pm & 2.08 & 2.00 & \pm & 1.00 & 4.00 & \pm & 1.00 & 2.00 & \pm & 2.65 \\
\hline week13 & 1.33 & \pm & 0.58 & 3.67 & \pm & 3.21 & 0.67 & \pm & 0.58 & 1.00 & \pm & 1.00 \\
\hline Total & \multicolumn{3}{|c|}{90.33} & \multicolumn{3}{|c|}{88.67} & \multicolumn{3}{|c|}{78.33} & \multicolumn{3}{|c|}{74.00} \\
\hline Mean & \multicolumn{3}{|c|}{$6.948^{a}$} & \multicolumn{3}{|c|}{$6.820^{a}$} & \multicolumn{3}{|c|}{$6.025^{a}$} & \multicolumn{3}{|c|}{$5.794^{\mathrm{a}}$} \\
\hline L.S.D. & \multicolumn{6}{|c|}{1.811} & \multicolumn{6}{|c|}{1.782} \\
\hline
\end{tabular}

${ }^{a}=$ significant difference highly exist; L. S. D. least significant difference; S.D. = significant difference.

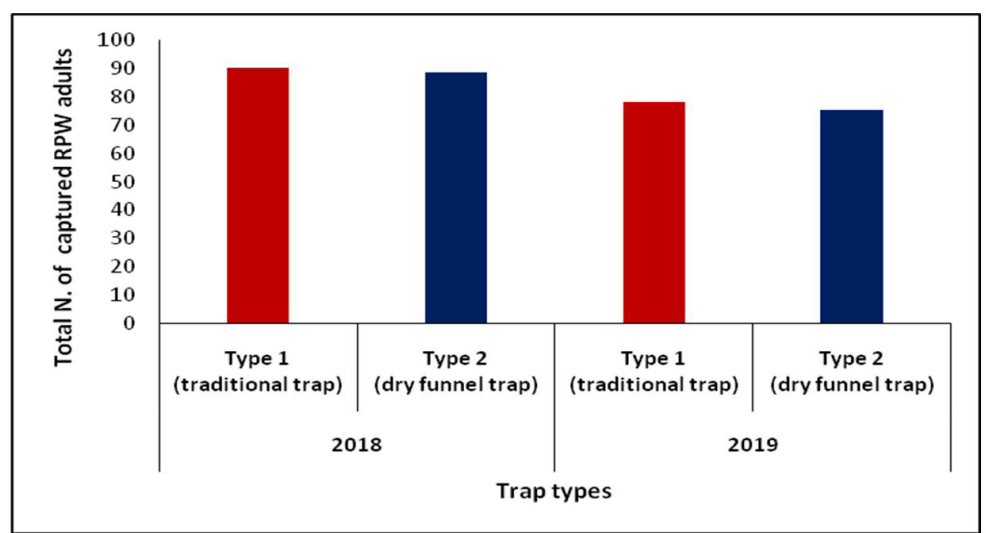

Figure 6. Comparison between two types of trap and its influence on captured adults of RPW during 2018 and 2019. 
trap bucket Figures 1 and 2 and the second one type 2 is funnel trap bucket Figures 1 and 2. Data indicated that there was no significant difference between the total numbers of RPW adults by two types of traps over the two seasons of study. It is clear that although there is no significant difference between the number of insects collected by the dry funnel trap and the traditional trap, the funnel trap is very suitable for places and farms that suffer from the lack of manpower. Otherwise, the traditional trap without renewing water every 2 weeks has turned into an insect attraction only to infect neighboring palms. While the dry trap does not need maintenance only add pheromone and keramone and renewed every 3 months as it is low cost compared to the cost of the Electrap ${ }^{\mathrm{TM}}$, which is very similar to funnel trap. These results were similar with those of El-Banna et al. (2017) mentioned that after comparing the efficacy of four trap design, they found that there was no significant difference between the total numbers of RPW adults by the trap design 2 (which was similar to our traditional trap type1) and trap design 4 (which was similar to our funnel trap type 2). Although there is no significant difference between the number of RPW collected by Electrap ${ }^{\mathrm{TM}}$ and the normal trap but Electrap ${ }^{\mathrm{TM}}$ need less effort and appropriate to the area that increased in the number of traps as a results activity of RPW (Al-Saroj et al., 2017).

\subsection{Sex ratio of $R$. ferrugineus adults attracted to aggregation pheromone traps in 2018 and 2019}

Obtained data in Figure 7 illustrated that the sex ratio of captured adults using aggregation pheromone traps. The numbers of attracted females were higher than males in experiment duration ( 3 month) two tested years (2018 and 2019). The sex ratios of male to female were 1: 1.43 and 1: 1.94 at 2018 and 2019 respectively. The results obtained are similar with those recorded by
Al-Saoud (2007) who stated that the adults of RPW were presented throughout the year, and the number of females was higher than the number of males. In Spain Sansano et al. (2008) found that during one year, the average number of trapped female was 2.5 times higher than the male's one. El-Sebay et al. (2010) observed that number of RPW female attracted to aggregation pheromone traps was considerable high than males during two successive years (2008 and 2009).

El-Shafei (2011) indicated that significantly more females were caught by 1.43 times than males during the whole year of 2009, and the results also indicated that significantly more females were caught by 1.76 times than males during the whole year of 2010. Zahra (2014) found that the numbers of females attracted to aggregation pheromone traps were generally twice as that of males. The sex ratios of male to female were 33.4: 66.6 during the tested year 2012-2013.

\subsection{Factorial analysis for the significance of different studied factors.}

Data in Table 3 and Figure 7 showed the effect of three factors (years, trap types, nano gel pheromone) on the number of RPW adults captured by aggregation pheromone trap for two seasons in 2018 and 2019. Analyzed and compared data revealed that there was no significant difference between the numbers of RPW adults captured by aggregation pheromone trap in the two seasons of study or in the two tested trap types. While there was significant difference between the recorded numbers of captured RPW adults by trap contained nano gel pheromone compared to the control trap contained normal aggregation pheromone for the two seasons of study 2018 and 2019. The same trend was noticed in collected RPW adults number of male and female.

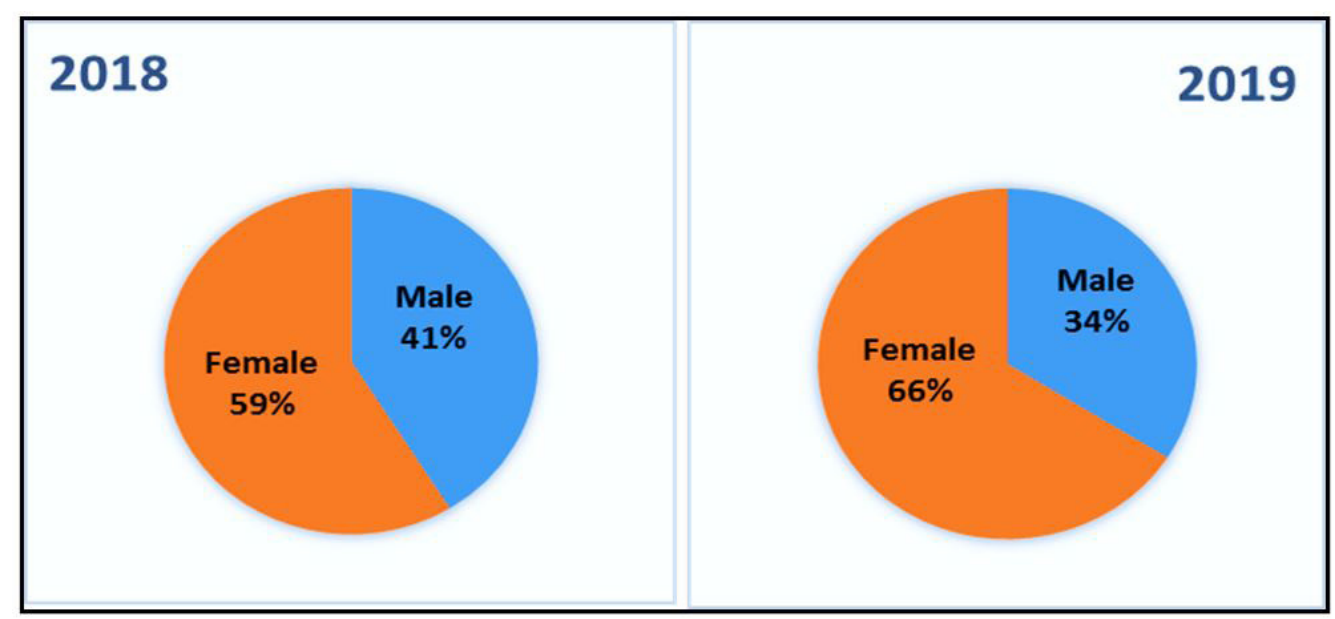

Figure 7. Sex ratio (males: females) of R. ferrugineus obtained from aggregation pheromone traps at Wardan village, in 2018 and 2019. 
Table 3. Factorial analysis for the significance of different studied factors on the number of RPW adults captured by aggregation pheromone trap during the two tested seasons 2018 and 2019.

\begin{tabular}{|c|c|c|c|c|c|}
\hline Factor & Level & $\mathbf{N}$ & \multicolumn{3}{|c|}{ Mean \pm SD } \\
\hline \multirow[t]{5}{*}{ Year } & 2018 & 156 & 3.44 & \pm 2.19 & $a^{*}$ \\
\hline & 2019 & 156 & 2.96 & \pm 2.40 & $\mathrm{a}$ \\
\hline & F. value & & & 1.75 & \\
\hline & P. value & & & 0.189 & \\
\hline & L.S.D. & & & 0.733 & \\
\hline \multirow[t]{5}{*}{ Trap types } & T1 Traditional & 156 & 3.24 & \pm 1.93 & a \\
\hline & T2 Dry funnel & 156 & 3.15 & \pm 2.01 & $\mathrm{a}$ \\
\hline & F. value & & & 0.09 & \\
\hline & P. value & & & 0.769 & \\
\hline & L.S.D. & & & 0.429 & \\
\hline \multirow[t]{5}{*}{ TRT } & control & 156 & 2.575 & \pm 1.86 & $b^{* *}$ \\
\hline & $\begin{array}{c}\text { Nano gel } \\
\text { pheromone. }\end{array}$ & 156 & 3.910 & \pm 2.06 & $\mathrm{a}$ \\
\hline & F. value & & & 5.73 & \\
\hline & P. value & & & 0.0173 & \\
\hline & L.S.D. & & & 0.4291 & \\
\hline \multirow[t]{5}{*}{ SEX } & Female & 156 & 1.99 & \pm 0.35 & $\mathrm{a}$ \\
\hline & Male & 156 & 1.21 & \pm 0.30 & $\mathrm{~b}$ \\
\hline & F. value & & & 22.27 & \\
\hline & P. value & & & 0.0003 & \\
\hline & L.S.D. & & & 0.350 & \\
\hline
\end{tabular}

*a=significant difference highly exist; $*$ * $\mathrm{b}=$ significant difference exist; $\mathrm{F}$ Value $=$ Mean square; $\mathrm{P}$ Value $=$ indicates probability; L.S.D $=$ least significant difference.

\section{Conclusion}

The use of RPW aggregation pheromone traps, both in early detection of the infestation or in the control as a mass trapping of RPW adults is one of the most important means of RPW integrated pest management. There is a need to develop and improve its efficiency therefore, this paper evaluated the effect of the use of red palm aggregate pheromone for the first time in the form of nano gel pheromone on the efficiency of the trap catchability of red palm weevils adults and compare between two trap types, traditional trap and dry funnel trap. Using of nano gel pheromone in RPW aggregation pheromone traps is recommended either for early detection of the infestation by RPW or in mass trapping because it improved the trap catchability by about $20 \%$. In addition. Although, there was no significant difference between dry funnel trap and the traditional trap, but it reduces the effort and costs of maintaining needed regularly to traditional trap especially in the farms with low number of labor.

\section{Acknowledgements}

The authors are grateful to Mr. Gamal Mohamed Mahmoud, the responsible of the farm in Village Wardan, Giza -Egypt for his acceptance of conducting Thee experiment in his farm as well as welcome to us and generosity and his help in the field during the work and provide all the necessary agricultural tools in helping to conduct this experiments.

\section{References}

ABBAS, M.S.T., HANOUNIK, S.B., SHAHDAD, A.S. and AIBAGHAM, S.A., 2006. Aggregation pheromone traps, a major component of IPM strategy for the red palm weevil, Rhynchophorus ferrugineus in date palms (Coleoptera: curculionidae). Journal of Pest Science, vol. 79, no. 2, pp. 69-73. http://dx.doi.org/10.1007/ s10340-005-0113-6.

ABD EL FATTAH, Y., EL-SHAFEI, W.K.M., EL-HELALY, A. and ABD EL-AHAB, A.S., 2019. Testing nano-pesticides toxicity against red palm weevil Rhynchophorus ferrugineus (Olivier) in Egypt. Plant Archives, vol. 19, pp. 1959-1968.

ABRAHAM, V.A., AL SHUAIBI, M.A., FALEIRO, J.R., ABUZUHAIRAH, R.A. and VIDYASAGAR, P.S.P.V., 1998. An integrated management approach for red palm weevil Rhynchophorus ferrugineus Oliv., a key pest of date palm in the Middle East. Sultan Qabus University Journal for Scientific Research. Agricultural Sciences, vol. 3, pp. 77-84.

ABUAGLA, A.M. and AL-DEEB, M.A., 2012. Effect of bait quantity and trap color on the trapping efficacy of the pheromone trap for the red palm weevil, Rhynchophorus ferrugineus. Journal of Insect Science, vol. 12, pp. 120. http://dx.doi.org/10.1673/031.012.12002. PMid:23451836.

AL SAOUD, A. and AJLAN, A., 2013. Effect of date fruits quantity on the numbers of red palm weevil Rhynchophorus ferrugineus (Olivier), captured in aggregation pheromone traps. Agriculture and Biology Journal of North America, vol. 4, no. 4, pp. 496-503. http://dx.doi.org/10.5251/abjna.2013.4.4.496.503.

AL SAOUD, A.H., YUSTA, R. and SARTO, V., 2016. Effect of trap color and trap Height above the ground on Pheromone mass-trapping of the Red Palm Weevil Rhynchophorus ferrugineus (Coleoptera: Dryophthoridae) in date palm groves in Abu Dhabi, UAE. Boletin de la SEA, no. 59, pp. 247-253.

AL-DOSARY, N.M.N., AL-DOBAI, S. and FALEIRO, J.R., 2016. Review on the management of red palm weevil, Rhynchophorus ferrugineus (Olivier) in date palm Phoenix dactylifera 1. Emirates Journal of Food and Agriculture, vol. 28, no. 1, pp. 34-44. http:// dx.doi.org/10.9755/ejfa.2015-10-897.

AL-SAOUD, A.H., 2007. Importance of date fruits in the red palm weevil Rhynchophorous ferrugineus Olivier (Coleoptera: Curculionidae). In: Proceedings of 3rd International Date Palm Conference, 2007, Abu Dhabi, UAE. Leuven: International Society for Horticultural Science, pp. 19-22.

AL-SAOUD, A.H., AL-DEEB, M.A. and MURCHIE, A.K., 2010. Effect of color on the trapping effectiveness of red palm weevil pheromone Traps. Journal of Entomology, vol. 7, no. 1, pp. 54-59. http://dx.doi.org/10.3923/je.2010.54.59.

AL-SAROJ, S., AL-ABDAllaH, E., AL-SHAWAF, A.M., AL-DANDAN, A.M., AL-ABDULLAH, I., AL-SHAGAG, A., AL-FEHAID, Y., ABDALLAH, A.B. and FALEIRO, J.R., 2017. Efficacy of bait free pheromone trap (Electrap ${ }^{\mathrm{TM}}$ ) for management of red palm weevil, Rhynchophorus ferrugineus (Olivier) (Coleoptera: curculionidae). Pest Management in Horticultural Ecosystems, vol. 23, pp. 55-59. 
BHAGAT, D., SAMANTA, S.K. and BHATTACHARYA, S., 2013. Efficient management of fruit pests by pheromone nanogels. Scientific Reports, vol. 3, no. 1, pp. 1294. http://dx.doi.org/10.1038/ srep01294. PMid:23416455.

COX, M.L., 1993. Red palm weevil, Rhynchophorus ferrugineus, in Egypt. FAO Plant Protection Bulletin, vol. 41, no. 1, pp. 30-31.

EL-BANNA, A., ABBAS, M.K., HALA, A. and IBRHIUM, T.M., 2017. Efficiency of food baits, synthetic attractants and trap type on Rhynchophorus ferrugineus (Olivier) trapping in palm plantations- Ismailia, Egypt- by Aggregation Pheromone Traps. Egyptian Academic Journal of Biological Sciences, vol. 10, no. 7, pp. 253-262. http://dx.doi.org/10.21608/eajb.2017.12112.

EL-BENDARY, H.M., ABDEL-WAHAB, A.S. and EL-HELALY, A.A., 2016. Entomo-toxic assay of nano-aluminum oxide and nanozinc oxide against Sitophilus Oryzae as a promising insecticide. Egyptian Journal of Zoology, vol. 174, no. 4083, pp. 1-8.

EL-HELALY, A.A., EL-BENDARY, H.M., ABDEL-WAHAB, A.S., EL-SHEIKH, M.A.K. and ELNAGAR, S., 2016. The silica-nano particles treatment of squash foliage and survival and development of spodoptera littoralis (Bosid) larvae. Journal of Entomology and Zoology Studies, vol. 4, no. 1, pp. 175-180.

EL-SABEA, A.M.R., FALEIRO, J.R. and ABO EL SAAD, M.M., 2009. The threat of red palm weevil Rhynchophorus ferrugineus to date plantations of the Gulf region of the Middle East: an economic perspective. Outlooks on Pest Management, vol. 20, no. 3, pp. 131-134. http://dx.doi.org/10.1564/20jun11.

EL-SEBAY, Y.M.A., ABBASS, M.K. and EL-SHEZLY, M.M., 2010. Seasonal abundance and population trends of red palm weevil, Rhynchophorus ferrugineus oliver (Coleopteran: curculioinidae). Journal of Plant Protection and Pathology, vol. 1, no. 8, pp. 577583. http://dx.doi.org/10.21608/jppp.2010.86896.

EL-SHAFEI, W.K.M. (2011). Ecological studies on the Red Palm Weevil, Rhynchophorus ferrugineus (Oliv). (Curculionidae: Coleoptera). Egypt: Faculty of Agriculture, Benha University, 180 p. M.Sc. Thesis in Economic entomology.

FALEIRO, J.R., AL-SHAWAF, A.M., AL-DANDAN, A.M., ALODHAYB, A., AL-RUDAYNI, A., ABDALLAH, A.B., PEIXOTO, M.P., VARGAS, R., BOTTOM, M., CHIDI, S., BORGES, R. and MAFRA-NETO, A., 2016. Controlled release products for managing insect pests. Outlooks on Pest Management, vol. 27, no. 4, pp. 175-180. http://dx.doi.org/10.1564/v27_aug_07.

FALEIRO, J.R., EL-SAAD, M.A. and AL-ABBAD, A.H., 2011. Pheromone trap density to mass trap Rhynchophorus ferrugineus (Coleoptera:Curculionidae Rhynchophoridae/Dryophthoridae) in date palm plantations of Saudi Arabia. International Journal of Tropical Insect Science, vol. 31, no. 1-2, pp. 75-77. http://dx.doi. org/10.1017/S1742758411000099.

GILAL, A.A., SOOMRO, M.H., MASTOI, M.I. and TALPUR, M.A., 2017. Performance of aggregation pheromone against red palm weevil at district Khairpur and Sukkur, Pakistan. Pakistan Entomologist, vol. 39, no. 2, pp. 9-12.

HABIB, D.M., MOUNA, N. and WIEM, H., 2017. Red Palm Weevil Rhynchophorus ferrugineus chemical treatments applied on ornamental palms in Tunisia: results of extensive experiments. International Journal of Agriculture Innovation and Research, vol. 5 , no. 6 , pp. 1062-1068.
HALLETT, R.H., GRIES, G., GRIES, R., BORDEN, J.H., CZYZEWSKA, E., OEHLSCHLAGER, A.C., PIERCE JUNIOR, H.D., ANGERILLI, N.P.D. and RAUF, A., 1993. Aggregation pheromones of two Asian palm weevils, Rhynchophorus ferrugineus and $R$. vulneratus. Naturwissenschaften, vol. 80, no. 7, pp. 328331. http://dx.doi.org/10.1007/BF01141908.

HASANIN, M.T., ELFEKY, S.A., MOHAMED, M.B. and AMIN, R.M., 2018. Production of well-dispersed aqueous crosslinked chitosan-based nanomaterials as alternative antimicrobial approach. Journal of Inorganic and Organometallic Polymers and Materials, vol. 28, no. 4, pp. 1502-1510. http://dx.doi.org/10.1007/ s10904-018-0855-2.

HASHIM, S.M., ABDULLAH, F.F. and TAWFIK, H.M. (2013). Monitoring studies of the red palm weevil Rhynchophorus ferrugineus using pheromone traps in palm tree orchards. In: AFPP-Palm Pest Mediterranean Conference, 2013, Nice, France. France: Association Française de Protection des Plantes, 2013.

HODDLE, M.S., AL-ABBAD, A.H., EL-SHAFIE, H.A.F., FALEIRO, J.R., SALLAM, A.A. and HODDLE, C.D., 2013. Assessing the impact of area wide pheromone trapping, pesticide applications, and eradication of infested date palms for Rhynchophorus ferrugineus (Coleoptera: Curculionidae) management in Al Ghowaybah, Saudi Arabia. Crop Protection (Guildford, Surrey), vol. 53, pp. 152-160. http://dx.doi.org/10.1016/j.cropro.2013.07.010.

MAHMUD, A.I., FARMINHAO, J. and VIEZ, E.R.A., 2015. Red palm weevil (Rhynchophorus ferrugineus Olivier, 1790): threat of palms. The Journal of Biological Sciences, vol. 15, no. 2, pp. 56-67. http://dx.doi.org/10.3923/jbs.2015.56.67.

MILOSAVLJEVIĆ, I., EL-SHAFIE, H.A., FALEIRO, J.R., HODDLE, C.D., LEWIS, M. and HODDLE, M.S., 2019. Palm ageddon: the wasting of ornamental palms by invasive palm weevils, Rhynchophorus spp. Journal of Pest Science, vol. 92, no. 1, pp. 143-156. http://dx.doi.org/10.1007/s10340-018-1044-3.

OEHLSCHLAGER, A.C., 1994. Use of pheromone baited traps in control of red palm weevil in the kingdom of Saudi Arabia. Saudi Arabia: Ministry of Agriculture, $17 \mathrm{p}$.

SALEM, S.A., EL-SALAM, A.A. and EL-KHOLY, M.Y., 2018. The optimal use of some types of natural food attractive as a tool to reduce the prediction and limit the spread of red palm weevil Rhynchophorus ferrugineus Olivier. Bio Science Research, vol. 15, no. 4, pp. 2911-2918.

SANSANO, M., GÓMEZ, S., FERRY, M. and DÍAZ, G., 2008. Ensayos de campo para la mejora de la eficacia de las trampas de captura de Rhynchophorus ferrugineus, Olivier (Coleoptera: Dryophthoridae), picudorojo de la palmera. Boletin de Sanidad Vegetal, vol. 34, no. 1, pp. 135-145.

SAS INSTITUTE, 2006. The SAS System for Windows 9.1. Cary: SAS Institute.

VACAS, S., PRIMO, J. and NAVARRO-LLOPIS, V., 2013. Advances in the use of trapping systems for Rhynchophorus ferrugineus (Coleoptera: Curculionidae): traps and attractants. Journal of Economic Entomology, vol. 106, no. 4, pp. 1739-1746. http://dx.doi.org/10.1603/EC13105. PMid:24020288.

ZAHRA, A.A.A., 2014. Studies on red palm weevil Rhynchophorus ferrugineus. Egypt: Faculty of Agriculture, Al-Azhar University, 111 p. M.Sc. Thesis in Economic entomology. 